\title{
TINJAUAN PUSTAKA MENGENAI PEMBERDAYAAN POTENSI MASYARAKAT DAN KELUARGA SEBAGAI UPAYA PERBAIKAN GIZI ANAK BALITA
}

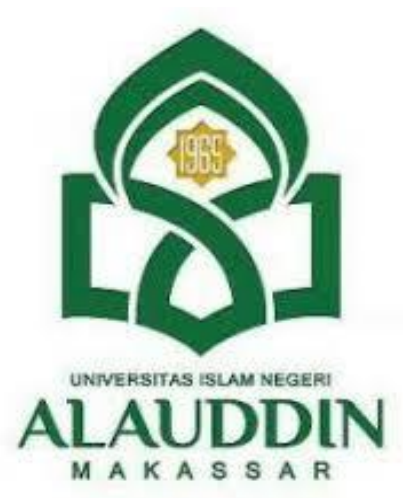

DOSEN PEMBIMBING :

Syamsul Alam, SKM., M.Kes.

OLEH :

Nurul Afina Fajriani

70200119063

PROGRAM STUDI KESEHATAN MASYARAKAT

FAKULTAS KEDOKTERAN DAN ILMU KESEHATAN

UNIVERSITAS ISLAM NEGRI ALAUDDIN MAKASSAR 


\section{PEMBERDAYAAN POTENSI MASYARAKAT DAN KELUARGA SEBAGAI UPAYA PERBAIKAN GIZI ANAK BALITA}

\section{Pendahuluan}

Gerakan Masyarakat Hidup Sehat (GERMAS) merupakan salah satu program yang sedang dijalankan pemerintah secara nasional. Salah satu sasarannya adalah ketercukupan gizi yang dikonsumsi oleh masyarakat termasuk anak anak yang sedang dalam masa pertumbuhan dan perkembangan (Buku Panduan Germas, 2015). Masalah gizi kurang dan gizi buruk pada anak balita masih menjadi masalahh gizi utama yang perlu mendapatkan perhatian lebih serius (Dinas Kesehatan Sulsel, 2007).

Status gizi merupakan prediktor kualitas sumber daya manusia. Status gizi dipengaruhi oleh asupan makanan. Konsumsi energi yang kurang dapat menyebabkan kekurangan gizi dan bila terus berlanjut dapat menyebabkan gizi buruk. Tingkat konsumsi energi yang cukup akan memberi pengaruh terhadap efisiensi penggunaan protein tubuh. Selanjutnya bila terjadi kekurangan protein dalam jangka waktu lama, akan mengakibatkan persediaan protein dalam tubuh semakin berkurang sehingga mengakibatkan Kwashiorkor. Menurut data Dinas Kesehatan Kota Semarang tahun 2011, prevalensi gizi kurang pada balita sebesar 0,98\% dan gizi buruk sebesar 0,06\% (Rarastiti, 2014).

Program pemberdayaan masyarakat merupakan suatu strategi yang dapat digunakan dalam meningkatkan potensi masyarakat dalam bidang kesehatan. Kegiatan masak abereng sebagai bagian dari kegiatan pemberdayaan masyarakat mampu meningkatkan partisipasi masyarakat. Kegiatan pemberdayaan masyarakat dan kemitraan bersama merupakan bagian dari

kegiatan dalam meningkatkan keikutsertaan masyarakat dalam intervensi keperawatan komunitas.11 Kegiatan optimalisasi keluarga dengan pendekatan lintas budaya dapat meningkatkan cakupan layanan kegiatan peningkatan gizi anak.12 Selain itu, program gerakan bebas gizi buruk di masyarakat dapat dilakukan melalui optimalisasi pos pelayanan terpadu (posyandu) plus dengan kerja sama lintas program dan sektoral.13 Oleh karena itu, keikutsertaan 
masyarakat dan keluarga dapat dioptimalkan dengan kegiatan pemberdayaan dan kemitraan dalam bidang kesehatan dalam mengatasi masalah kurang gizi pada balita.

\section{Upaya Perbaikan Gizi Balita}

Karbohidrat memberikan asupan $6075 \%$ dari jumlah energi total. Satu gram karbohidrat mengandung 4,1 kalori. Berdasarkan hasil analisis karbohidrat dari 100 g roti rumput laut lawilawi (Ceulerpa racemosa) substitusi tempe menunjukkan bahwa kadar karbohidrat tertinggi pada perlakuan 1: 3 (25\% rumput laut lawi-lawi dan $75 \%$ tempe) sebesar $56,10 \%$. Hal ini dikarenakan gabungan dari karbohidrat kompleks yang ada pada rumput laut lawilawi dan karbohidrat sederhana yang ada pada tempe pada formulasi ini menghasilkan kandungan karbohidrat total yang tinggi. Kandungan karbohidrat terendah pada perlakuan 1:0 (100\% rumput laut lawi-lawi) sebesar 48,96\%. (Syarfaini Dkk, 2019)

Dalam penelitian Syarfaini Dkk (2019) Analisis Kandungan Zat Gizi Bakpao Abon Ikan Kembung Jantan dengan Subtitusi Rumput Laut Merah dengan hasil kandungan karbohidrat yang paling tinggi terdapat pada bakpao subtitusi 1:1 dengan komposisi ikan dan rumput laut yang sama dan terendah terdapat pada bakpao subtitusi 1:3 dimana komposisi rumput laut pada perbandingan ini paling banyak dibandingkn pada perbandingan bakpou lainnya. Penelitian ini menyatakan bahwa semakin tinggi komposisi rumput laut pada bakpou maka semakin menurun kadar karbohidratnya namun dengan adanya subtitusi dan perbandingan yang sama maka kadar karbohidratnya jauh lebih tinggi dibandingkan dengan perbandingan komposisi bakpao lainnya karena rumput laut dapat berkontribusi terhadap peningkatan kadar karbohidrat.

\section{Penanggulangan Stunting Berbasis Pemberdayaan}

Pemberdayaan adalah proses memampukan masyarakat dalam upaya meningkatkan kesadaran, kemauan, dan kemampuan masyarakat secara sistematis untuk mengembangkan diri, mempunyai kemauan dan kemampuan untuk memilih dan upaya untuk meningkatkan peran serta aktif masyarakat dalam mencegah dan mengatasi masalah dengan kegiatan dari, oleh, dan untuk masyarakat (Waryana, et al. 2015). Pemberdayaan masyarakat merupakan segala upaya fasilitasi yang bersifat musyawarah, guna meningkatkan pengetahuan dan kemampuan masyarakat, agar 
mampu mengidentifikasi masalah yang dihadapi, potensi yang dimiliki, merencanakan, dan melakukan penyelesaiannya dengan memanfaatkan potensi masyarakat setempan (Kementerian Kesehatan RI, 2015).

Inti pemberdayaan (empowerment) yang mengarah pada kemandirian masyarakat. Dalam pemberdayaan masyarakat, dimensi partisipasi masyarakat menjadi sangat penting. Partisipasi bukan hanya berati keterlibatan masyarkat dalam pelaksanaan program atau masyarakat hanya ditempatkan sebagai objek, melainkan harus diikuti dengan keterlibatan masyarakat dalam pembuatan keputusan dan proses perencanaan pembangunan atau masyarakat ditempatkan sebagai subjek utama yang harus menentukan jalnnya pembangunan. Dua elemen penting yang ditekankan pada teori ini ialah partisipasi (participation) dan pemberdayaan (empowerment) (Waryana, et al. 2015).

Pemberdayaan masyarakat di bidang kesehatan bertujuan untuk menumbuhkan kesadaran, pengetahuan, dan pemahaman akan kesehatan individu, kelompok, dan masyarakat, menimbulkan kemauan yang merupakan kecenderungan untuk melakukan suatu tindakan atau sikap untuk meningkatkan kesehatan mereka, dan menimbulkan kemampuan masyarakat untuk mendukung terwujudnya perilaku sehat (Adisasmito, 2010).

Penanggulangan stunting berbasis pemberdayaan pada ibu rumah tangga adalah upaya untuk menumbuhkan kesadaran, pengetahuan, dan pemahaman akan pencegahan stunting di desa Donomulyo. Ibu rumah tangga dalam hal ini berperan sebagai subjek yang berperan aktif dalam penanggulangan stunting. Pemberdayaan sebenarnya merupakan sebuah alternatif pembangunan yang sebelumnya dirumuskan menurut cara pandang developmentalisme (moderinisasi) yang dulunya berorientasi pada negara dan modal, sementara paradigma baru (pemberdayaan) lebih terfokus pada masyarakat lokal yang dibangun secara partisipatif.

Keluarga merupakan unit terkecil dalam masyarakat yang terdiri dari suami istri atau suami, istri, dan anaknya atau ayah dan anaknya, atau ibu dan anaknya. Sesuai dengan fungsi pemeliharaan kesehatan, keluarga mempunyai peran dan tugas di bidang kesehatan yang perlu dipahami dan dilakukan, salah satu diantaranya mengenal masalah kesehatan. 
Partisipasi ibu rumah tangga dalam penanggulangan stunting berbasis pemberdayaan adalah keterlibatan individu-individu anggota masyarakat untuk bertanggung jawab baik mental maupun emosi terhadap tujuan penanggulangan stunting. Ibu rumah tangga memberikan dukungan berupa bentuk dan jenis partisipasi yang semuanya disesuaikan dengan kebutuhan (perencanaan, pelaksanaan, pemanfaatan, dan pengawasan, serta penilaian).

Pentingnya peran ibu rumah tangga tidak hanya pada pendidikan anak, tetapi juga meliputi peranannya terhadap kondisi kesejahteraan keluarga. Keterlibatan ibu rumah tangga dalam pemenuhan kebutuhan rumah tangga merupakan fenomena yang tidak asing lagi di kehidupan masyarakat. Ibu memiliki peran penting dalam pemenuhan gizi anak melalui penyelenggaraan makan keluarga.

Menurut Kementerian Kesehatan RI (2018), terdapat tiga hal yang harus diperhatikan dalam pencegahan stunting, yaitu salah satunya perbaikan terhadap pola makan. Masalah stunting dipengaruhi oleh rendahnya akses terhadap makanan dari segi jumlah dan kualitas gizi, serta seringkali tidak beragam. Istilah "Isi Piringku" dengan gizi seimbang perlu diperkenalkan dan dibiasakan dalam kehidupan sehari-hari. Dalam satu porsi makan, setengah piring diisi oleh sayur dan buah, setengahnya lagi diisi dengan sumber protein (baik nabati maupun hewani) dengan proporsi lebih banyak daripada karbohidrat. 


\section{Daftar Pustaka}

Adisasmito, W. 2010. Sistem Kesehatan. PT. Raja Grafindo Persada. Jakarta.

Alam S \& Syahrir S. 2016 Faktor-Faktor Yang Berhubungan Dengan Teknik Menyusui Pada Ibu Di Puskesmas Pattallassang Kabupaten Takalar, 8 (2), 130-138.

Anderson Et, Mcfarlane Jm. Community As Partner: Theory And Practice In Nursing. Am J Nurs. 1996;96(10).

Endang Sutisna Sulaeman, Bhisma Murti. Waryana (2015). Peran Kepemimpinan, Modal Sosial, Akses Informasi, Serta Petugas Dan Fasilisator Kesehatan Dalam Pemberdayaan Masyarakat Bidang Kesehatan. Kesmas: National Public Health Journal 9 (4), 353-361.

Kemenkes RI, 2018, Hasil Utama Riskesdas 2018, Kemenkes Ri: Badan Penelitian Dan Pengembangan Kesehatan.

Kementerian Kesehatan Republik Indonesia. 2015 Buku Panduan Germas. Jakarta: Kementerian Kesehatan Republik Indonesia.

Rarastiti, C. N., \& Syauqy, A. 2014 Hubungan Karakteristik Ibu, Frekuensi Kehadiran Anak Ke Posyandu, Asupan Energi Dan Protein Dengan Status Gizi Anak Usia 1-2 Tahun (Doctoral Dissertation, Diponegoro University)

Rondhianto, Susanto T, Sulistyorini L. 2014 Gerakan Bebas Gizi Buruk (Gerbasgibur) Melalui Nursing Feeding Center Dalam Posyandu Plus Di Kecamatan Jelbuk Kabupaten Jember. In: Posiding Seminar Nasional 'Kontribusi Penelitian Dan Ppm Dalam Menghasilkan Insan Humanis Dan Profesional'; Yogyakarta. Lppm Universitas Negeri Yogyakarta;. P. 86105.

Susanto T, Sulistyorini L. 2014 Family Friendly Dalam Optimalisasi Keberlangsungan Pemberian Asi Ekslusif Melalui Integrasi Fcn Dan Tnm Di Jember. Jurnal Injec.;1(2):15666.

Syarfaini Dkk, 2019 Analisis Kandungan Zat Gizi Roti Rumput Laut Lawilawi (Ceulerpa Racemosa) Subtitusi Tempe Sebagai Alternatif Perbaikan Gizi Masyarakat, 11 (1), 94-106. 